\title{
IX. On some new species of animal concretions
}

\section{Thomas Taylor}

To cite this article: Thomas Taylor (1846) IX. On some new species of animal concretions, Philosophical Magazine Series 3, 28:184, 36-46, DOI: 10.1080/14786444608645350

To link to this article: http://dx.doi.org/10.1080/14786444608645350

册 Published online: 30 Apr 2009.

Submit your article to this journal $\pi$

Џ Article views: 3

Q View related articles $₫$ 
[ 36$]$

IX. On some Nere Species of Animal Concretions.

By Thomas Taylor, Surgeon.

To Richard Taylor, Esq.

Dear Sir,

$A S$ the Catalogue of the Calculi belonging to the Royal $A$ College of Surgeons has now been published some months, and there consequently remains no further necessity for silence, I purpose in the following paper to redeem the promise I formerly made, of describing some of the more remarkable of the concretions which have been discovered during the examination of that very large collection; and also to detail the experimental proofs on which the assertions as to their composition were founded in the short notice which you did me the favour of inserting in this Journal in May 1844.

I do this the more willingly, as it was considered advisable to omit the details of the analyses in the Catalogue. Moreover, the Catalogue having but a limited circulation, many of the new facts that have been elicited would not otherwise be generally known. I shall, however, confine myself in this paper to the notice only of such concretions as are entirely new, or whose composition has been either imperfectly or incorrectly described. For the historical account of the successive steps by which our present knowledge of these bodies has been obtained, and for the description of the more common species of calculi, I must refer to the Catalogue itself.

\section{Urinary Calculus from the Iguana, consisting of Urate of Polass.}

Small and unimportant quantities of urate of potass may occasionally be detected in human urinary calculi, but no instance of this salt constituting an entire calculus has hitherto been described. There are three specimens of this description in the College collection, which resemble each other in every respect save in size. Two of them were described in the MS. Catalogue of Sir Hans Sloane's collection as "Piedra de Yguana," and there is little doubt but that they were taken from the urinary bladder of some of the large Iguanas or tree lizards of South America. The other concretion had no history, but had been described as "a mixed calculus in which uric acid predominates." Although much larger, it was so similar in composition and general appearance to the others, that there does not appear any reason to doubt its having a similar origin. In their external characters these concretions resembled calculi composed of the mixed phosphates, being made up of 
concentric layers of a dirty white colour with a shade of pink. They were of an ovoid figure, but all of them were remarkable for being flattened in a peculiar manner on one side.

When heated before the blowpipe they consumed like a uric acid calculus, but left a fusible salt which spread over the platina foil, and tinged the outer flame violet. When heated in a test-tube, carbonate and hydrocyanate of ammonia with a little empyreumatic oil and water were given off. The carbonaceous residue, when treated with water, gave a solution which had a strong alkaline reaction, effervesced with acids, and emitted a slight odour of prassic acid. Tartaric acid and chloride of platina produced in the solution precipitates indicative of the presence of potass.

Water digested upon the powdered calculus afforded a solution which deposited small scales of suburate of potass upon being evaporated; the liquor gave no precipitate with a salt of lime, consequently no soluble oxalate was present.

When digested with caustic potass, ammonia was freely evolved, and the whole dissolved with the exception of a little flocculent matter. The alkaline solution, when mixed with muriatic acid, gave a copious precipitate of uric acid. It was therefore evident that these concretions consisted chiefly of urate of potass mixed with urate of ammonia.

The relative proportion of their constituents was estimated in the following manner:-

$19.10 \mathrm{grs}$, when submitted to a current of dry air at $212^{\circ}$ Fahr., lost 0.32 water, $=1.67$ per cent. The dried powder was digested in boiling acetic acid, which decomposed the urate of potass and left a residue which weighed $15.02 \mathrm{grs}$., $=78^{\circ} 64$ per cent. This residue was found to consist of uric acid, containing a small trace of oxalate of lime.

The acetic solution being evaporated to dryness was boiled with proof spirit; the whole dissolved with the exception of some light yellow flocks of animal matter, which amounted to $0.52 \mathrm{gr}$., $=2.73$ per cent.

The spirituous solution being evaporated to dryness, the earthy and alkaline acetates it had contained were decomposed by the addition of muriatic acid; the mixture was evaporated to dryness and heated red-hot in a platina crucible. The residue dissolved entirely in water, with the exception of $0 \cdot 06$ gr. of phosphate of lime. The aqueous solution was mixed with carbonate of ammonia, a precipitate fell, which when dried and ignited was equivalent to $0.36 \mathrm{gr}$. of pure lime. It contained however a trace of phosphate of lime.

The solution from which the above precipitates had been separated was evaporated to dryness and the residue heated 
red-hot. It was redissolved in water, and mixed with alcohol and chloride of platina. Chloride of platinum and potassium was thrown down, which when washed with alcohol and carefully dried weighed 10.32 grs., $=1.09 \mathrm{PO}$.

The quantity of ammonia was estimated by boiling the powdered calculus in a solution of potass, transmitting the ammonia evolved through diluted muriatic acid, and precipitating it in the ordinary manner by chloride of platina. 11.40 grs. yielded $4 \cdot 57$ of chloride of platina and ammonia, $=3 \cdot 10$ per cent. I do not, however, place much confidence in this mode of estimating the ammonia. The result of the analysis of this calculus, calculated in 109 parts, is therefore as follows: it is compared with an analysis of the calculus which had no history, in which the quantity of potass is rather greater :-

Uric acid mixed with a trace of oxalate of lime $78.64 \quad 78.36$

Potass . . . . . . . . . . . . . $10.42 \quad 13.19$

Ammonia . . . . . . . . . . . . $3 \cdot 10 \quad 3.09$

Lime . . . . . . . . . . . . . . . $1 \cdot 89 \quad 1 \cdot 49$

Magnesia . . . . . . . . . . . . 0.000000

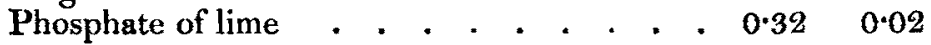

Animal matter . . . . . . . . . . . $2 \cdot 73 \quad 0.43$

Water . . . . . . . . . . . . . $1.67 \quad 1.80$

Sulphate of soda with chloride of sodium .

$\overline{98 \cdot 77} \overline{98 \cdot 67}$

By another analysis, in which the quantity of potass was alone estimated by calcining the calculus until nothing but carbonate of potass was left, and precipitating the dissolved salt by chloride of platina, 10.72 per cent. of potass was found in the first, and 19.07 in the second calculus.

The potass in these concretions is probably derived from the leaves and other vegetable matter on which the Iguana partly subsists, while the carnivorous or insectivorous habits of the reptile are indicated by the large quantity of uric acid they contain.

\section{Urinary Calculus from the Sturgeon, consisting of Diphosphate of Lime. Beluga stones.}

These calculi are found by the fishermen of the Caspian Sea and of the Volga in a species of Sturgeon (Acipenser Huso, Linn.). The statements of different authors as to the situation of the stone in the fish, are very conflicting, some describing it as occurring in the air..bladder, others in the head and stomach. In Schrober's Memorabilia Russico-Asiatiea, as quoted by Klaproth, it is sajd to be nost frequently found in a small pouch communicating with the pancreatic 
duct; his description is however confused and anatomically incorrect. The subjoined extracts from the works of Pallas* leave no doubt as to these concretions being taken from the

* "Les pêcheurs rencontrent assez souvent dans les gros biélougas, la pierre dont j'ai parlé, qui est encore un problème. Ils la vendent à un prix assez modique, de doux à trois roubles. Tous les pêcheurs à qui j'en ai parlé, m'ont assuré qu'on la trouve dans le gros boyau, qui leur sert à se vider et à jeter leurs œufs. On rencontre quelquefois des pierres dans les gros esturgeons ordinaires; elles sont semblables à celles des biélougas. On en trouve aussi dans les gros barbeaux, mais elles sont d'une espèce différente. Les pierres de biélouga sont ovales, unies, et quelques-unes grumelés assez grossièrement; d'autres sont triangulaires et toutes plates. Cette variété, dans la forme et la place qu'elles occupent, prouve que c'est une vraie pierre, et non une arête. Elles ont toutes la couleur et la texture de l'arête. Lorsqu'on les brise, on trouve dans leur substance des rayons luisans spathiques qui tendent de la circonférence au centre; outre la texture écailleuse qu'on distingue à la première superficie, il se détache de l'intérieur de quelques-unes de ces pierres un noyau; il a la même substance que la pierre, mais une autre forme; il ne se trouve pas toujours au centre. J'en ai vu plusieurs qui pesoient jusqu'à trois onces; je les croyois plus pesantes d'après leur' grosseur. On peut en raper avec la lame d'un couteat, mais avec peine. J'ai essayé d'en mettre dans des acides et je n'y ai apperçu aucune marque d'effervescence. En Russie, on se sert de cette pierre comme remède domestique, dans les accouchemens laborieux, pour les maladies de l'urètre et celles des enfans; il est très en vogue, et l'on a grand tort. On en fait prendre dans de l'eau à très-petite dose. On attribue les mêmes vertus, et nombre d'autres, à la pierre qu'on rencontre quelquefois dans la vessie urinaire des sangliers, qu'on appelle Kabannoï Kamen, pierre de sanglier; elle est beaucoup plus chère que celle du biélouga."-Voyages de Pallas, tom. i. p. 683.

"On fend le cartilage du dos pour en retirer les nerfs; on les lave et étend sur des perches pour les faire sécher.

"C'est en partageant ce cartilage dans toute sa longueur que l'on trouve quelquefois dans les plus gros ichthyocolles cette pierre si vantée. On ne l'apperçoit que lorsque le couteau s'arrête au moment où il la touche. Cette pierre est renfermée dans la chair ronge glanduleuse, qui est adhérente à la partie postérieure de l'épine du dos, et elle tient lieu de rognons. Elle est dans une petite peau particulière, qui remplit l'intérieur de cette espèce de glande. Je rapporte ici ce que M. Sokolof a pu apprendre de plus certain sur sa vraie position, des pêcheurs les plus instruits, qui assuroient en avoir trouvé quelques-unes. A' l'extérieur, elle est un peu molle et humide lorsqu'elle est fraichement tirée, mais elle durcit aussitôt qu'elle est à l'air. C'est dans les pêches qui se font près d'Astrakan qu'on la rencontre le plus souvent. Elle n'est jamais plus grosse qu'un œuf de poule. Elle est ovale et assez plate un peu concave; où elle a l'angle qui adhère au cartilage un peu coụrbé."-Voyages de Pallas, 1789, vol.ii. p. 486.

"In visceribus uropœis Huscnum maximorum et æate provectiorum sæpius reperitur Calculus ovalis, depressus, hinc concavus, solidus, albus, intus Zeolithi fere instar a centro radiatus, nitidusque, cujus chemica anaIysis adhuc deest. Hunc plebs Rossica, et honoratiores etiam, pro magno medicamento uragogo et parțum promovente astimant atque infantibus propinant, unde a piscatoribus jretio non exiguo redimuntur, Calculi $\mathrm{H}_{u^{-}}$ sonis (Bjelushie Kamen) nomine."-Zoographia Rosso-Asiatica, vol. iii. p. 87 . 
dilated ureter or from the common cloacal termination of the gut of the fish.

These concretions have generally a flattened oval figure, their centre being often depressed or slightly concave. They vary considerably in size, but are usually about that of a hen's egg. Their surface is unequal but quite smooth, and of a yellowish-white colour. When broken they present a highly crystalline structure, consisting of fine plates or needles radiating from the centre to the circumference, but which are made up of very thin concentric layers adhering firmly together. Fragments of these calculi are translucent, and their interior is of a pure white colour. They are exceedingly scarce, and are highly esteemed for their supposed medicinal virtues. Dr. Cook informs us that the powder is highly commended as a diuretic and lithontriptic, and that the common people in the neighbourhood of the Volga take from ten to sixty grains, scraped fine in a little water, three or four times a day when the case is dangerous.

The composition of these calculi was first determined by Klaproth, but the earliest description of them is to be found in the Philosophical Transactions for 1748 .

The specimen analysed by Klaproth had been received from Prof. Pallas. It weighed above seven ounces troy, and consisted of albumen 1, water 24, phosphate of lime 71.50, sulphate of lime 0.50 .

$17.13 \mathrm{grs}$. of one of the specimens in this collection, previously calcined, gave by solution in dilute muriatic acid and precipitation by oxalate of ammonia, 13.87 grs. of carbonate of lime, which is $=17.54$ of the diphosphate of lime; $100 \mathrm{grs}$. of the same calculus gave-

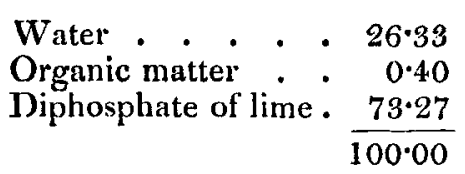

$$
\begin{aligned}
& \text { By calculation. } \\
& \begin{array}{l}
25 \cdot 60=5 \text { atoms. } \\
1 \cdot 13 \\
\frac{73 \cdot 27}{100 \cdot 00}=1 \text { atom. }
\end{array}
\end{aligned}
$$

The Beluga stones therefore consist of an atom of diphosphate of lime combined with 5 atoms of water. The water is necessarily over-estimated in the analysis, on account of the organic matter being partially soluble in the diluted acid.

By another and more rigid analysis, I found the calculus to consist of $32.21 \mathrm{CaO}, 40.33 \mathrm{PO}_{5}$, and $26.33 \mathrm{HO}$, which would give 72.54 per cent. of diphosphate of lime. 'This calculus has also been analysed by Prof. Wöhler, who ascertained that four of the five atoms of water are driven off at $392^{\circ}$ Fahr, while the last atom is expelled by a red heat. 
The phosphoric acid is therefore in the tribasic state, and the formula of the salt will be $\mathrm{PO}_{5} 2(\mathrm{CaO}), \mathrm{HO},+4$ aq. I think it right to state that the analysis of this concretion had been printed some months previous to the publication of Prof. Wöhler's paper, and its analysis was made in 2843.

\section{Intestinal Concretions.}

The composition of the different kinds of intestinal concretions has been very little studied by chemists; a circumstance the more remarkable, as they present many points of interest both to the chemist and physiologist. The only description of these bodies to be found in the systematic works on chemistry, is almost wholly derived from the paper of Messrs. Fourcroy and Vauquelin, published in the 4th volume of the Annales du Muséum National.

By these chemists intestinal concretions were divided into the following species:-1, Calculi consisting of superphosphate of lime; 2, of phosphate of magnesia ; 3 , of phosphate of magnesia and ammonia; 4, of a biliary matter analogous to the colouring matter of the bile; 5 , resinous concretions; 6 , fungous concretions; and lastly, hair-balls. Their description of these bodies is however exceedingly slight and imperfect, and much inferior in accuracy to their previous researches on urinary calculi. In no instance did they determine the relative proportion of the constituents of the earthy concretions, and under the head of resinous concretions two essentially distinct species were included.

In the Catalogue I have endeavoured to supply these deficiencies by submitting most of these calculi to quantitative analysis, and by the addition of some new species. The following list includes all the intestinal concretions with which I am at present acquainted :- 1 , Calculi consisting of animal hairs; 2, of vegetable hairs; 3, of ellagic acid-the oriental bezoar; 4, of resino-bezoardic acid-the occidental bezoar; 5 , of phosphate of magnesia and ammonia; 6, of diphosphate of magnesia; 7 , of diphosphate of lime; 8 , of oxalate of lime; 9 , of ambergris.

\section{The Ellagic Acid Calculus.-The Oriental Beroar.}

The composition of this species of calculus was described in a report to the Museum Committee in 1841, and in May 1843 I was permitted to insert a short notice as to its composition in the London and Edinburgh Philosophical Magazine. Since that period the ellagic acid calculus has been examined by MM. Merklein and Wöhler, who have confirmed my state- 
ments as to its nature*. The result of a careful comparison of the chemical characters of these concretions with those of ellagic acid prepared from the gall-nut $\dagger$ so fully established their identity, that I did not think it necessary to corraborate my statement by an ultimate analysis, especially as from the limited quantities of the calculus on which I could operate, and the facility with which ellagic acid becomes oxidized when dissolved in an alkali, I did not feel certain that I could ensure that perfect purity without which an organic analysis is wholly valueless. Its ultimate analysis has however been made by MM. Merklein and Wöhler, who have found it to agree with the analysis of ellagic acid by M. Pelouze, minus one atom of hydrogen.

The following description of the ellagic acid calculus, its properties and history, 1 sball quote verbatim from the College Catalogue published in Julv 1845, as it conveys in a condensed form the results of a long and troublesome series of experiments.

"Ellagic acid calculi are generally of an ovoid figure; their outer surface is smooth, polished, and of a deep olive or greenish brown colour; internally they are brown; they are made up of thin concentric layers, which in some cases adhere so slightly together, as to cause the calculus to fall to pieces on attempting to divide it with a saw. When any of the outer layers of these calculi are removed, the exposed surface readily acquires a high polish by slight friction, and when cut or scraped they assume a waxy lustre. These calculi invariably contain some foreign body as their nucleus, which is generally a small twig or seed.

* Ann. der Chemie und Pharm., August 1845. If by the following passage, "Aus dieser Zusammensetzung und den oben angegebenen Eigenschaften der Bezoarsäure folgt ferner der merkwürdige Umstand, dass diese Substanz, wie bereits von 'Th. Taylor vermuthet wurde, in der That nichts Anderes ist als Ellagsäure oder die Säure, die zuerst von Chevreul aus den Galläpfeln dargestellt und von Braconnot näher untersucht worden ist. Um nịcht den geringsten $Z$ weifel hierüber zu lassen, haben wir selbst Ellagsäure aus Galläpfeln dargestellt und ihre Eigenschaften mit denen der Bezoarsäure verglichen; sie zeigten sich vollkommen identisch," MM. Merklein and Wöhler intend to imply that some doubt existed in my mind as to the composition of this concretion, I beg to state that such was not the case; and it is difficult to conceive on what grounds they could form such an opinion, as in the notice alluded to I simply stated the fact in the most concise and positive terms that could be made use of.

+ For the opportunity of doing this on rather a Iarge scale, $I$ am indebted to my friend $\mathrm{Mr}$. 'T. Morson, who kindly placed at my disposal a large quantity of the residue left in the preparation of gallic acid, and it gives me much pleasure to have an opporturity of acknowledging this and sinilar favours. 
"The chemical characters of the constituent of these calculi agree so exactly with those of ellagic acid procured from the infusion of gall-nuts, as to leave no doubt of their being composed principally of that substance. When heated they do not fuse, but emit a slight balsamic odour and partially sublime; if more highly heated they catch fire, burn with a low flame, give off the smell of burning wood, and leave behind a carbonaceous ash. If the powder of the calculus be heated in a glass tube a yellow sublimate is produced, which condenses in the form of long spear-shaped crystals of a yellow colour, with a shade of green. These crystals da not differ in their chemical habitudes from the powder of the calculus, and they are identical in shape and appearance with those procured from the ellagic acid of the gall-nut when similarly treated. When the calculus is reduced to powder and diffused through water, several days elapse before the whole of the powder is deposited, and the water remains opalescent even for weeks. It is also difficult to separate the powder by filtration, as the liquid passes turbid for some time.

« Ellagic acid calculi easily dissolve, with the exception of a few flocks, in a cold solution of caustic potass or soda. The solution is of a deep brownish red colour, with a shade of green; when the ellagic acid is, however, freed from some extractive or colouring matter with which it is generally mixed in the ealculus, the solution is of so deep a yellow as to appear red when viewed in bulk. Muriatic acid throws down from the potass solution a greenish, buff-coloured powder, while the supernatant liquor is of a light red colour. If the precipitate be examined by the microscope, it is seen to consist of small thread-like particles, generally blunt, but sometimes tapering at their extremities, and which are occasionally twisted or curved, especially if the solution from which they were thrown down was hot: they are not transparent, and can scarcely be termed crystals.

"When the potass solution is exposed to the air, oxygen and carbonic acid are absorbed, the solution becomes much darker colqured, and a silky greenish yellow precipitate is deposited, consisting of ellagate of potass. This precipitate appears under the microscope as thin rectangular plates, frequently arranged in stellate groups. If a current of carbonic acid is passed through the solution, a buff-coloured precipitate of ellagate of potass is thrown down, while the supernatant liquid remains of a dark reddish colour.

"Ellagic acid calculi are very sparingly soluble in solution of ammonia; the liquid acquires a yellow colour, which on ex- 
posure to the air becomes brown and turbid. The small quantity of ellagic acid dissolved is precipitated by an acid.

"Concentrated sulphuric acid readily dissolves these calculi when assisted by a gentle heat. The solution is of a greenish brown colour, and is precipitated by dilution with water. The precipitate has the form of minute prisms arranged in stellate groups; the extremities of some of the prisms are blunt, others are pointed.

"When mixed with nitric acid, the ellagic acid calculus dissolves. If the acid be strong or slightly warmed, effervescence takes place, nitrous fumes are given off, and a solution is produced of a beautiful pink-red colour, similar to that produced by the action of nitric acid upon uric acid. The red colour quickly disappears upon standing; on being heated, a deep yellow solution remains, from which crystals of oxalic acid may be obtained by evaporation. Ammonia added to the solution causes it to assume a red colour, but does not render it turbid.

' $\epsilon$ The ellagic acid is best obtained from these calculi by dissolving the powdered calculus in a weak solution of caustic potass, and transmitting through it a current of carbonic acid. The precipitate which falls is to be digested in diluted muriatic acid, by which the potass is removed, and tolerably pure ellagic acid remains. During the whole of the operation great care must be taken to prevent the contact of atmospheric air; for when dissolved in alkaline liquids, ellagic is quickly converted into a species of ulmic acid. It is not improbable that catechuic acid is sometimes present in these calculi.

"This species of intestinal concretion appears to have been first examined by Fourcroy and Vauquelin, and is included in their class of resinous Bezoars*. It was shortly afterwards examined by Berthollet, and subsequently by other chemists, all of whom failed in deciding upon its true nature; even so recently as 1843 this calculus was described by M. Lippowitz as consisting of a peculiar organic acid, for which he proposed the name of Bezoaric acidt.

"The concretions analysed by Berthollet, and of the properties of which he has given a very accurate account, had been

* "La seconde variété d'une couleur brune ou violacée, sans saveur amère, presque insoluble dans l'alcohol, entièrement soluble dans les alcalis, donnant dans cette dernière dissolution une liqueur qui devient rouge purpurine, lorsqu'elle s'épaissit et se sèche à l'air: fournissant à la distillation un sublimé concret, jaune, d'une saveur et d'une couleur de suie, insoluble dans l'eau et dans l'alcohol." - Annales du Muséum National, tom. iv. 334. 463.

$\uparrow$ Simon's Beiträge zur Phys. und Pathol. Chemie und Mikroskopie, B. i. 
presented to the Emperor Napoleon by the Shah of Persia. They were of a greenish brown colour externally, and brown within; they had an oval figure, and their surface was highly polished; they were formed of irregular concentric layers, and in the centre of all of them was some vegetable matter; their sp. gr. $=1 \cdot 463$. They were regarded by Berthollet as consisting of the woody fibre (lignin) of the food of the animal, and he conjectures that they must have been taken from the stomach, on account of the little alteration which the vegetable matters that formed their nucleus* had undergone.

"'The constituent of the ellagic acid calculus is likewise described by John under the name of Bezoarstofft; and Leopold Gmelin thinks it probable that the calculi examined by John were identical in composition with those analysed by Berthollet + , and that they consisted of a species of ulmin arising from the decomposition of woody fibre or lignin.

"From the descriptions which Tavernier, Kæmpfer, and other Oriental travellers have given of the Oriental Bezoar, corroborated by the analyses of Fourcroy and Berthollet, there is no doubt that it is identical with the ellagic acid concretion above described. The signs by which a true Oriental Bezoar might be distinguished were, according to Tavernier, by steeping it in hot water, and observing whether the liquid became coloured, or the stone lost in weight. If either of these occurred, the stone was to be regarded as fictitious: but the best test was to apply a red-hot iron wire to the calculus, when, if it melted and permitted the iron to enter, it was certainly fictitious. Another test consisted in smearing a piece of paper with chalk, and rubbing the calculus over it. The genuine stone always left a greenish mark. All these criteria would be fulfilled by the ellagic acid calculus, but by none of the other species $\S$.

"This species of concretion was the most valued of the Bezoars, and is denominated by Kæmpfer the 'verus et pretiosus Pasahr,' from which word, by a corruption of sound, he believes the word Bezoar to have been derived.

"With regard to the origin of this concretion, we have the fullest and most satisfactory evidence. W. Methold, Fryer, Tavernier and Kæmpfer all agree that it is taken most frequently from the alimentary canal of a species of wild goat termed Pasen by the Persians, which inhabits the mountainous ridges in Persia, particularly in the province of Chorasaan or

* Mémoires de la Société d'Arcueil, ton. ii. p. 448.

+ Chem. Schr. iii. 38.

+ Handbuch der Chemie, B. ii. S. 828, 1488.

In the Sloanian MS. Catalogue all the ellagic acid caleuli wete termed East Indian or Oriental Bezonrs. 
Chorasmia. Tavernier states that they likewise come from a province of the kingdom of Golconda. The account as to the exact situation of the stone is however not so cleat. Most writers indicate the maw or stomach: Kæmpfer says it is found in the pylorus; 'sive productior quarti, quem vocant ventriculi fundus*', and that the natives are in the habit of ascertaining how many stones are contained in the stomach by feeling through the parietes of the abdomen, the value of the animal being considerably enhanced by their presence. When recently taken from the animal, they are said to be somewhat soft, or of the consistence of a hard-boiled egg, and that in order to preserve them it was customary to place them in the mouth, and retain them there until they acquired greater hardness.

"The Oriental Bezoar was not however confined to the wild goats, or to the ruminant tribes, as the Pedra Bugia or Ape stone also consists of ellagic acid. These concretions were held in higher esteem than those from the Goat, and were generally included, for the sake of preserving them, in a small cavity scooped out of two portions of a very light wood, which were held together by hoops wove from the twigs of the Rotang cane. There is in the Museum a specimen preserved in this manner. Kampfer informs us that they were found in a species of ape termed Antar by the Mongols, which he believes to be the Babianum cynocephalum. The composition of these concretions renders their origin no longer a matter of uncertainty, and confirms, in a very remarkable manner, the statements of Tavernier and Kæmpfer, that they are derived from the juices of the plants on which the animals fed."

MM. Merklein and Wöhler have proposed that the word ellagic should be changed for that of bezoaric acid, partly because the German word "Gall," when reversed, is not capable of being converted into ellagic, and partly from its want of enphony. If we were however, for the sake of euphony, to reject all the inharmonious appellations which the industry of modern chemists has introduced into the science, we might alter half the names at present in use; besides, as the ellagic acid was first procured from the gall-nut by Chevreul and subsequently named by Braconnot, I think it a matter of courtesy to adhere to its French derivation. The term bezoaric is also peculiarly improper, inasmuch as it would imply that the entire class of bezoars consisted of this peculiar acid.

$$
\begin{aligned}
& \text { I remain, dear Sir, } \\
& \text { Yours most truly, }
\end{aligned}
$$

New Bridge Street, Nov. 20, 1845. Thomas Taylor. 